Political Science Review LIX: 927-939.

Oppenheimer, Bruce I. 1985. "Changing Time Constraints on Congress: Historical Perspectives on the Use of Cloture" in Lawrence C. Dodd and Bruce I. Oppenheimer, eds., Congress Reconsidered. Washington, D.C.: Congressional Quarterly Press.

\section{Part-Time Faculty In Political Science: Stepchildren of the Profession}

Nancy E. McGlen

and

Meredith Reid Sarkees

Niagara University

Editor's Note: The National Education Association has recently issued a report, "Report and Recommendations on Part-Time, Temporary and Nontenure Track Faculty Appointments." As reported in the Chronicle of Higher Education (March 9, 1988, p. A13), the NEA recommends that "Part-time instructors should be given the same salary and fringe benefits, prorated, as full time faculty members. They should be included in faculty governance procedures. They should be used only to teach specialized courses, replace absent professors, or address unexpected enrollment increases. And they should be hired on a full-time basis whenever possible."

The full report is available from NEA, Office of Higher Education, 1201 16th Street, NW, Suite 320, Washington, DC 20036.

$\mathbf{T}$ he employment of part-time faculty at universities and colleges has recently become a headline topic (Wall Street journal, 1986, Time, 1987, Chronicle of Higher Education, 1987). Projections are for further growth in the employment of these "academic stepchildren" as institutions of higher education attempt to grapple with the twin demons of declining enrollments and rising costs. What are the dimensions

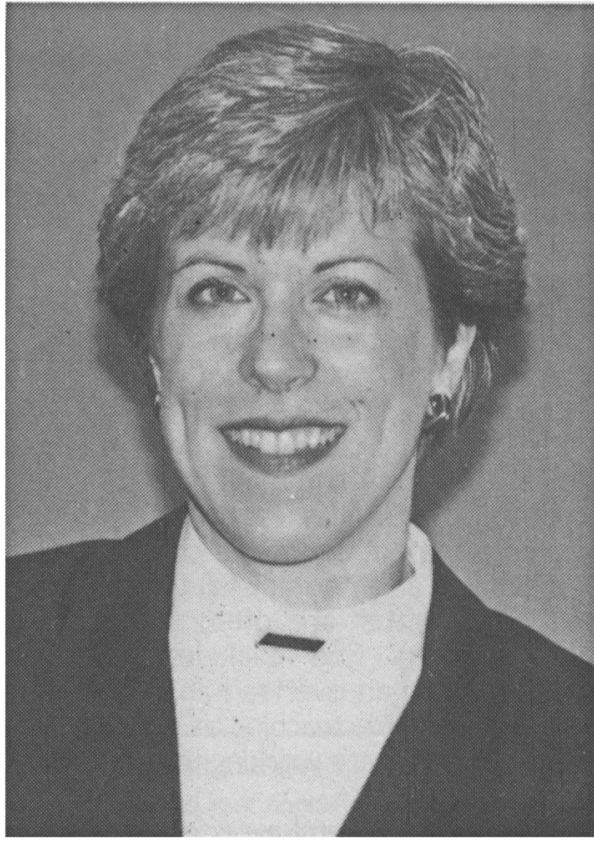

NANCY E. MCGLEN

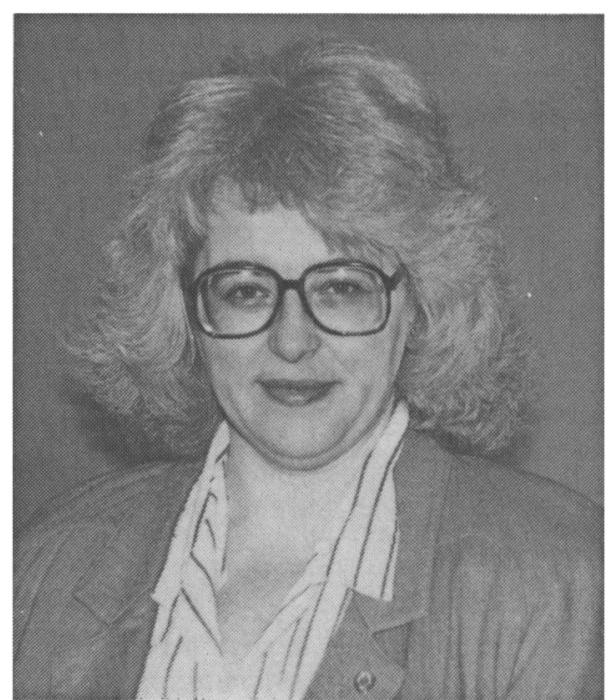

MEREDITH REID SARKEES 
of part-time employment in political science and the possible implications of this phenomenon for the profession?

\section{Part-time Faculty: An Overview}

The actual number of part-time faculty is not easily established. Part of the problem is the difficulty in defining part-time faculty. After discussing a variety of contrasting descriptions, Judith Grappa (1984, p. 5) defines part-time faculty as "anyone who (1) teaches less than the average full-time faculty load, or (2) has less than a full-time faculty assignment and range of duties, or (3) may have a temporary full-time assignment" (the latter are often called academic gypsies). She excludes full-time faculty handling an overload and graduate assistants who are teaching at the institutions where they are working toward their degrees.

The failure of federal agencies to collect and publish figures on part-time employment in academia also contributes to our

\section{Most authorities estimate}

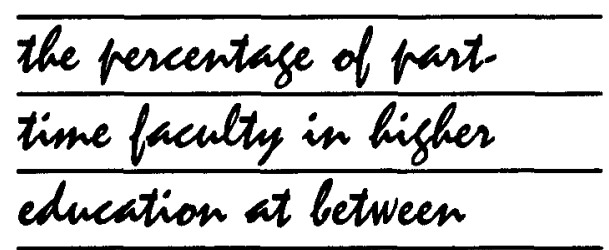

\section{$30 \%$ and $40 \%$ of all}

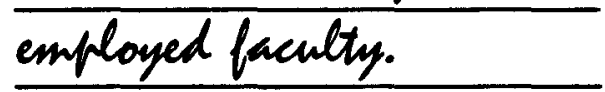

lack of knowledge about part-time faculty. in the absence of complete figures, we are forced to rely on partial and often out-ofdate projections. Most authorities estimate the percentage of part-time faculty in higher education at between $30 \%$ and $40 \%$ of all employed faculty (Grappa, 1984, p. 10; Leslie, Kellams, and Gunne, 1982, pp. 23-24). However, part-time faculty are not distributed equally in all institutions of higher education. Community colleges employ the largest number of part-timers, generally estimated at over $50 \%$ of the faculty (Grappa, 1984, p. 23). Four-year colleges average 25 to $33 \%$ of their faculty in part-time positions, while the fewest part-timers (13-26\%) are found in universities (Grappa, 1984, pp. 23-24; Leslie, et al., 1982, p. 19). The variation among types of institutions is related to the type of clientele served, the nature of the programs offered, and the demands on faculty. Financial exigencies, locale, and program offerings also shape the number of part-timers in any given institution (Leslie et al., 1982, ch. 2). The decline in the student-aged population, the glut of baby boomer Ph.D.'s, the need for market-attractive programs, and the economic troubles in higner education are all expected to push the use of part-time faculty even higher in the next two decades.

\section{Part-time Faculty in Political Science}

Little information exists on the academic specialty of part-time faculty. A survey in 1978 found that noncredit, offcampus, and nontraditional instruction had the highest percentage of part-time faculty, while graduate instruction had the fewest (Leslie, et al., 1982, p. 21). In order to gauge the number of part-time faculty in political science we have relied on the data collected by the American Political Science Association in its annual Survey of Departments. This mail survey, conducted every year since 1972, asks departments to indicate the rank, tenure-track status, gender and ethnic background of all full and part-time faculty. Part-time faculty are defined to be those members of the department who are not employed on a full-time basis in the institution. Graduate students are not to be included in the count of part-time faculty. The main drawback to the data is the uneven response rate of different types of institutions. While the overall response rate has averaged $49 \%$, the departments least likely to have part-time faculty, Ph.D. programs, have an average response rate of $82 \%$. Moreover, community colleges are not included in the survey. Thus, any figures of the number of part-time political science faculty drawn from this data base will be expected to underestimate the total number of part-timers. With this 


\section{Table 1 \\ Percent Full- and Part-Time Faculty in Political Science Departments, 1972-1973 to 1985-1986a}

\begin{tabular}{cccc}
\hline Year of Survey & $\begin{array}{c}\text { Percent Full-Time } \\
\text { Faculty }\end{array}$ & $\begin{array}{c}\text { Percent Part-Time } \\
\text { Faculty }\end{array}$ & $\begin{array}{c}\text { Percent Expanded } \\
\text { Definition of } \\
\text { Part-Time Faculty }\end{array}$ \\
\hline $1972-19736$ & 82.1 & 17.9 & 20.5 \\
$1973-1974$ & 85.7 & 14.3 & 21.0 \\
$1974-1975$ & 87.2 & 12.8 & 19.1 \\
$1975-1976$ & 86.0 & 14.0 & 18.3 \\
1976.1977 & 84.7 & 15.3 & 19.7 \\
1977.1978 & 86.1 & 13.9 & 17.2 \\
$1978-1979$ & 85.7 & 14.3 & 18.6 \\
$1979-1980$ & 85.0 & 15.0 & 19.8 \\
$1980-1981$ & 84.9 & 15.1 & 19.6 \\
$1981-1982$ & 84.8 & 15.2 & 19.0 \\
$1982-1983$ & 83.1 & 16.9 & 21.0 \\
1983.1984 & 80.1 & 19.9 & 24.7 \\
$1984-1985$ & 84.7 & 15.3 & 20.9 \\
$1985-1986$ & 81.5 & 18.5 & 22.5 \\
\hline
\end{tabular}

${ }^{a}$ Figures represent the percent of total faculty from all Departments in each category.

In the 1972.73 Survey of Departments regular faculty members who held joint appointments with other aca. demic departments were included in the count of part-time faculty. in all other years respondents were instructed to count as part-time faculty only those members who were not employed on a full-time basis in the institution.

Includes Part-Time and Non-Tenure Track Full-Time Faculty.

Source: American Political Science Association. 1972-1973 to 1985-1986. Survey of Departments. Washington: The American Political Science Association.

caveat in mind, Table I presents the overtime percentages of part-time faculty teaching in political science departments.

As the table makes clear, there has been a gradual upward trend in the number of part-time political science faculty. The high point appears to have been the 1983-84 school year when nearly $20 \%$ of faculty from the responding institutions were employed part-time. If we use Grappa's definition of part-timers and include those full-timers in non-tenure track positions, the percentage of part-timers increases to a peak of nearly $25 \%$ in 1983-84. See Table I. This group of faculty in part-time and temporary appointments has been referred to as "gypsies" to indicate their uncertain academic life style and status. The true gypsy status of political science part-timers is clouded by the fact that approximately $50 \%$ of the part-time faculty are listed as tenure-track part-time (data not shown on table). If this is true, it is highly unusual. Other research has shown that few part-time faculty have any chance of obtaining tenure (Grappa, 1984, p. 79).

If we examine the number of part-timers by institutional type, our results closely parallel the findings of others. Research universities (classified as those offering the $\mathrm{Ph}$.D.) generally have the smallest percentage (12\%) of their political science faculty employed part-time.' Masters-only programs employ a considerably larger percentage (18\%) of part-timers, generally more than undergraduate programs. Among the latter, public institutions have a smaller percentage $(13 \%)$ of their faculty employed part-time than do private undergraduate programs $(19 \%)$. The largest percentage $(23 \%)$ of part-timers is found in undergraduate programs that combine political science with another discipline. However, given the low response rate of undergraduate institutions, especially the combined departments, we have to be cautious about drawing any 
Table 2

Gender of Part-Time and Full-Time Faculty in Political Science Departments

\begin{tabular}{|c|c|c|c|c|c|c|c|c|c|c|}
\hline \multirow{2}{*}{$\begin{array}{l}\text { Year of } \\
\text { Survey }\end{array}$} & \multicolumn{2}{|c|}{$\begin{array}{l}\text { Percent of } \\
\text { Total Faculty }\end{array}$} & \multicolumn{2}{|c|}{$\begin{array}{c}\text { Percent of } \\
\text { Full-Time } \\
\text { Faculty }\end{array}$} & \multicolumn{2}{|c|}{$\begin{array}{c}\text { Percent of } \\
\text { Part-Time } \\
\text { Faculty }\end{array}$} & \multicolumn{2}{|c|}{$\begin{array}{l}\text { Percent of } \\
\text { Expanded } \\
\text { Definition of } \\
\text { Part-Time } \\
\text { Faculty }{ }^{b}\end{array}$} & \multicolumn{2}{|c|}{$\begin{array}{l}\text { Percent of } \\
\text { Full-Time } \\
\text { Tenure-Track } \\
\text { Faculty }\end{array}$} \\
\hline & Men & Women & Men & Women & Men & Women & Men & Women & Men & Women \\
\hline $1972.73^{a}$ & 89.3 & 10.7 & 91.9 & 8.9 & 80.8 & 19.2 & 80.5 & 19.5 & 91.5 & 8.5 \\
\hline $1973-74$ & 89.7 & 10.3 & 91.1 & 8.9 & 81.3 & 18.7 & 83.5 & 16.5 & 91.3 & 8.7 \\
\hline $1974-75$ & 89.0 & 11.0 & 90.0 & 10.0 & 81.8 & 18.2 & 82.8 & 17.2 & 90.4 & 9.6 \\
\hline $1975-76$ & 88.3 & 11.7 & 89.4 & 10.6 & 81.4 & 18.6 & 80.7 & 19.3 & 90.0 & 10.0 \\
\hline $1976-77$ & 88.2 & 11.8 & 89.4 & 10.6 & 81.6 & 18.4 & 80.9 & 19.1 & 90.0 & 10.0 \\
\hline 1977.78 & 88.4 & 11.6 & 90.0 & 10.0 & 78.2 & 21.8 & 78.3 & 21.7 & 90.5 & 9.5 \\
\hline $1978-79$ & 88.1 & 11.9 & 89.4 & 10.6 & 80.3 & 19.7 & 80.6 & 19.4 & 89.9 & 10.2 \\
\hline $1979-80$ & 87.6 & 12.4 & 89.0 & 11.0 & 79.3 & 20.7 & 80.4 & 19.6 & 89.4 & 10.6 \\
\hline$|980-8|$ & 87.3 & 12.7 & 88.7 & 11.3 & 79.4 & 20.6 & 79.4 & 20.6 & 89.2 & 10.8 \\
\hline $1981-82$ & 89.6 & 13.1 & 88.4 & 11.6 & 79.0 & 21.0 & 78.9 & 21.1 & 88.8 & 11.2 \\
\hline $1982-83$ & 86.5 & 13.5 & 87.9 & 12.1 & 79.2 & 20.8 & 78.6 & 21.4 & 88.5 & 11.5 \\
\hline $1983-84$ & 87.2 & 12.8 & 88.0 & 12.0 & 84.0 & 16.0 & 83.7 & 16.3 & 88.4 & 11.6 \\
\hline $1984-85$ & 85.1 & 14.9 & 87.0 & 13.0 & 74.4 & 25.6 & 75.9 & 24.2 & 87.5 & 12.5 \\
\hline 1985.86 & 85.6 & 14.4 & 87.3 & 12.7 & 78.1 & 21.9 & 77.9 & 22.4 & 88.0 & 12.1 \\
\hline
\end{tabular}

an the 1972-73 Survey of Deportments regular faculty members who held joint appointments with other academic departments were included in the count of part-time faculty. In all other years respondents were instructed to count as part-time faculty only those members who were not employed on a full-time basis in the institution.

Includes Part-Time and Non-Tenure Track Full-Time Faculty.

Source: American Political Science Association. 1972-73 to 1985-86. Survey of Departments. Washington: The American Political Science Association.

firm conclusions in this vein.

Table 2 reports the distribution of gender in political science. lgnoring the high and low years, women generally constitute $20 \%$ of the part-time faculty.

This is nearly twice the percentage of women found among the full-time faculty. Using Grappa's expanded definition of part-timers (including full-time faculty on non-tenure track lines) gives us essentially the same picture. For example, in the $1985-86$ school year, only $12.1 \%$ of all fulltime tenure track political science faculty were women, while more than $22 \%$ of the gypsies (full-time non-tenure track plus part-time faculty) were women. Looking at other demographic categories, we find in any given year less than $6 \%$ of all parttime faculty are Black, while Spanish-surnamed, resident aliens, and Asian Americans, each make up generally less than $2 \%$ of the part-time faculty in political science departments.

\section{Conclusions and Implications for the Profession}

The overall impact of part-timers on the profession is going to be influenced by several factors, including the motivations and ambitions of the part-timers. The literature on part-time faculty suggests that a variety of career goals and backgrounds characterize part-time faculty in all fields (Tuckman, 1978). At one extreme are the $28 \%$ of the part-timers who are "fullmooners," full-time professionals from other fields who only teach a course on an occasional basis. This group is joined by retired professors (estimated at 3\%) and graduate students who teach for other institutions (Tuckman, 1978). These persons generally are satisfied with their part-time status, seeing it as a means of augmenting their income. At the other end of the spectrum, however, are the "hopeful full- 
timers" (estimated at 17\% of all parttimers), who believe that their part-time or temporary work will lead to a full-time tenure track position (Tuckman, 1978). We do not know specifically how many political science part-timers fall into these categories. Obviously, for those who are "hopeful full-timers," their choice of career has not yet led to the desired outcome. Moreover, the outlook for these part-timers is not promising. Only a few of them can expect to find full-time permanent employment, especially given the projections regarding increased use of part-timers to solve the financial crisis brought about by a declining college aged population.

For the field of political science, the projected growth in the number of part-time faculty threatens the profession in a number of ways. First, it means it may be more difficult to encourage promising undergraduates to pursue the Ph.D.. especially if they see many Ph.D.'s underemployed. Second, with more part-time colleagues, full-time faculty will increasingly have to take on the duties of advisement, administration, and department governance, tasks they would have been able to share with full-time faculty (Leslie et al., 1982), ch. 5; Grappa, 1984, p. 64). Third, research productivity will be threatened as full-timers have to devote more time to administrative affairs. Part-time faculty may be willing to engage in some research, but the lack of time and resources (for instance few part-timers have access to

... women fenerally

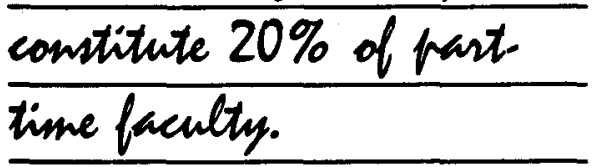

computers) should severely limit their productivity (Leslie et al., 1982, ch. 5; Grappa, 1984, pp. 65-68). Fourth, the academic profession as a whole is threatened by part-timers whose salary scale and easy replaceability undermine the professoriate (Leslie et al., 1982, ch. 6).

The Council of the American Political Science Association, perhaps recognizing these future problems, urges institutions in its Guidelines on Employment Upportunities to "make more flexible use of part-time positions," but, it notes that these posi tions should "carry full academic status equivalent rank, promotion opportunities, equal rates of pay, commensurate depart mental participation and commensurate fringe benefits, including access to research

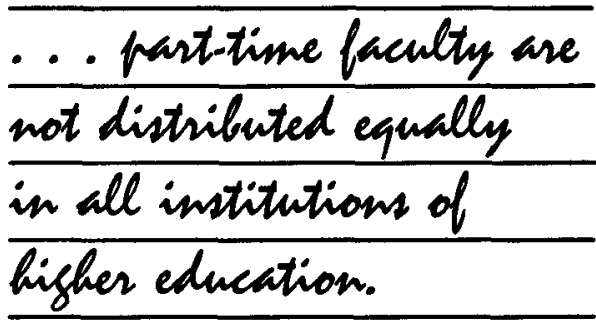

resources" (Schier, 1985, p. II). If fully adopted by all institutions offering courses in political science, this policy would help to prevent many of the problems anticipated with the growth in part-time faculty.

\section{About the Authors}

Nancy E. McGlen is an associate professor of political science at Niagara University. She is also chairperson of the department of political science and criminology and criminal justice at Niagara University. Her major area of research is women and politics.

Meredith Reid Sarkees is an assistant professor in the department of political science and criminology and criminal justice at Niagara University. Her major areas of research are international relations theory and American foreign policy.

\section{Notes}

The data for this paper is from the American Political Science Association's Annual Survey of Departments, 1972-73 to 1985-86. We would like to thank the staff of the Association, especially Pat Spellman, for their help in providing this material. We would also like to thank Nora Groves from the Polymetrics Lab at Ohio State for her help in answering some questions about the data.

'Figures represent the mean percentage of part-time faculty for each institutional type for the years 1975-1986. 


\section{References}

Bowen, Ezra. January 12, 1987. Academia's New Gypsies. Time, p. 65.

Grappa, Judith M. 1984. Part-time Faculty: Higher Education at a Crossroads. ASHE. ERIC Higher Education Report No. 3. Washington: Association for the Study of Higher Education.

Heller, Scott. January 28, 1987. Part-time Teachers Turn to Unions to Alter Status as "Academic Stepchildren." The Chronicle of Higher Education, pp, 1, 12.

Leslie, David W., Samuel E. Kellams, and G.
Manny Gunne. 1982. Part-time Foculty in American Higher Education. New York: Praeger.

Pierce, R. Taeza. September 25, 1986. "Gypsy" Faculty Stir Controversy at U.S. Colleges. Wall Street journal.

Schier, Richard F. ed. 1985. A Guide to Professional Ethics in Political Science. Washington: The American Political Science Association. Tuckman, Howard P. 1978. Who is Part-time Academe? in Part-time Foculty Series. Washington: American Association of University Professors. 